\title{
Obesity on a High-Fat Diet: Role of Hypothalamic Galanin in Neurons of the Anterior Paraventricular Nucleus Projecting to the Median Eminence
}

\author{
Sarah F. Leibowitz, ${ }^{1}$ Akira Akabayashi, ${ }^{2}$ and Jian Wang ${ }^{1}$ \\ 1The Rockefeller University, New York, New York 10021, and 'School of International Health, The University of Tokyo, \\ Tokyo, Japan
}

Previous studies have suggested that the peptide galanin (GAL) in the hypothalamus is related to the preference of an animal for dietary fat. The present report investigates this relationship further to identify the specific GAL-synthesizing cell groups involved and to characterize their association to circulating glucose or hormones and their possible contribution to body fat deposition. Male albino Sprague Dawley rats were tested in different feeding paradigms with diets containing the macronutrients, fat, carbohydrate, or protein. These studies, using multiple techniques, identify a cell group in the hypothalamus that expresses GAL and that shows a shift in peptide activity in close relation to dietary fat, circulating glucose, and body fat. In all paradigms, a rise in fat intake, from 10 to $30 \%$, is associated with reduced levels of insulin and corticosterone and normal glucose levels, whereas a further increase in fat ingestion (>30\%) leads to hyperglycemia along with greater adiposity. In the hypothalamus, GAL gene expression, peptide production, and peptide release rise significantly (by 40\%) in association with fat ingestion, showing no relation to either carbohydrate or protein ingestion. This change is highly site specific, evident predominantly in GAL-synthesizing neurons in the anterior parvocellular region of the paraventricular nucleus (aPVN) and in GAL-containing terminals in the external zone of the median eminence (ME). Positive correlations detected between mRNA abundance in the aPVN and GAL peptide in the ME support the existence of an aPVN-ME projection system related to fat intake and fat deposition. When activated by dietary fat, the contribution of this projection to body fat is suggested by consistent positive correlations between aPVN-ME GAL and either dietary fat, circulating glucose, or body fat and by significantly higher GAL levels (+30\%) in obesity-prone compared with obesity-resistant rats. This evidence supports a role for this hypothalamic GAL projection system in the development of obesity produced by the overconsumption of fat.

Key words: glucose; hypothalamus; insulin; carbohydrate; in situ hybridization; immunohistochemistry
There is considerable evidence linking the ingestion of a fat-rich diet to the development of obesity (Blundell, 1987; Kanarek and Orthen-Gambill, 1988; Golay and Bobbioni, 1997). Studies in animals (Boozer et al., 1995) as well as in humans (Lissner and Heitmann, 1995) demonstrate that body fat is more closely related to the amount of fat ingested than to total caloric intake (Boozer et al., 1995). Moreover, caloric intake and meal size rise significantly on a high-fat diet (Ramirez et al., 1989; Ramirez and Friedman, 1990; Thomas et al., 1992; Shor-Posner et al., 1994).

The neurobiology of these phenomena remains to be understood. There is some evidence that the peptide galanin (GAL), which is expressed in multiple hypothalamic nuclei (Melander et al., 1986; Bartfai et al., 1993; Merchenthaler et al., 1993), may be linked to fat ingestion (Akabayashi et al., 1994a; Leibowitz, 1995). When injected into the hypothalamus of satiated rats, GAL stimulates food intake and, in some conditions, preference for dietary fat (Kyrkouli et al., 1986; Tempel et al., 1988; Crawley et al., 1990). It also reduces energy expenditure (Menendez et al., 1992) and sympathetic activation of brown adipose tissue (Nagase

Received Aug. 27, 1997; revised Dec. 23, 1997; accepted Jan. 14, 1998.

This work was supported by United States Public Health Service Grant MH43422. We thank Y. Dam of the Obesity Core Research Center at St. Luke's-Roosevelt Hospital for assistance with the insulin and glucose determinations and Hi Joon Yu and Jesline Alexander for their excellent technical assistance.

Correspondence should be addressed to Dr. Sarah F. Leibowitz, The Rockefeller University, 1230 York Avenue, New York, NY 10021.

Copyright (ㄷ) 1998 Society for Neuroscience $0270-6474 / 98 / 182709-11 \$ 05.00 / 0$ et al., 1996). Moreover, in normal weight rats given a choice of macronutrient diets (Akabayashi et al., 1994a), GAL levels and gene expression, in a specific hypothalamic area, are found to be positively correlated with the ingestion of fat but not of carbohydrate or protein. The area identified in this relationship is the paraventricular nucleus (PVN), which is known to have an important role in the control of food intake (Swanson and Sawchenko, 1983; Luiten et al., 1987; Leibowitz, 1995; Leibowitz and Hoebel, 1997). Whereas there is little direct evidence linking GAL to body weight or body fat, genetically obese rodents that normally prefer fat-rich diets (Castonguay et al., 1982; Romsos and Ferguson, 1982) have increased GAL gene expression in the hypothalamus compared with their lean littermates (Beck et al., 1993; Jhanwar-Uniyal and Chua, 1993; Mercer et al., 1996).

This enhancement of GAL activity in relation to dietary fat or body fat may be a response to changes in circulating hormones, such as insulin, adrenal steroids, and gonadal steroids. A systematic analysis of these hormones, as they relate to GAL in different dietary and body weight conditions, has yet to be performed. They are known to have effects of their own on food intake, metabolism, and body weight (Wade and Schneider, 1992; Tempel and Leibowitz, 1994; Kaiyala et al., 1995; Leibowitz and Hoebel, 1997) and, in addition, to have marked influence on the expression of GAL in the hypothalamus (Merchenthaler et al., 1993; Akabayashi et al., 1994b; Kalra and Kalra, 1996; Tang et al., 1997; Wang and Leibowitz, 1998).

Whereas these findings are suggestive, more extensive analyses 
of the hypothalamic GAL system and its multiple cell groups are needed to demonstrate its functional significance in relation to the behavioral process of fat ingestion as well as to body fat deposition. Using techniques of in situ hybridization and immunohistochemistry as well as radioimmunoassay (RIA) of peptide levels in micropunched tissue, we sought via this series of experiments to identify the specific neuronal cell groups within the PVN and their projection sites related to dietary fat. The results of these analyses demonstrate a close relationship between the activity of a specific GAL-synthesizing neuronal cell group and the terminal area in the hypothalamus and the natural pattern of fat ingestion of an animal. This GAL projection system is additionally linked to circulating levels of glucose as well as to body fat, both of which are markedly enhanced by the ingestion of fat.

Parts of this paper have been described in published abstracts (Alexander et al., 1996; Wang et al., 1996).

\section{MATERIALS AND METHODS}

Animals. Adult male Sprague Dawley rats (325-350 gm; Charles River Breeding Laboratories, Kingston, NY) were individually housed in a fully accredited American Association for Accreditation of Laboratory Animal Care facility $\left(22^{\circ} \mathrm{C}\right.$; lights off at 3:30 P.M. for $\left.12 \mathrm{hr}\right)$, according to institutionally approved protocols as specified in the NIH Guide to the Use and Care of Animals.

Diets. All rats were maintained ad libitum on food and water for a period of 4 weeks. In experiment $1(n=25)$, rats were allowed to choose from a single high-carbohydrate diet (HCD; $25 \%$ protein, $65 \%$ carbohydrate, and $10 \%$ fat; $3.75 \mathrm{Kcal} / \mathrm{gm}$ ) and a high-fat diet (HFD; $25 \%$ protein, $15 \%$ carbohydrate, and $60 \%$ fat; $5.10 \mathrm{Kcal} / \mathrm{gm}$ ). In experiment 2 $(n=10)$, rats were given access to separate sources of protein (casein), carbohydrate (dextrin, sucrose, and corn starch), and fat (lard) as described previously (Shor-Posner et al., 1994). In experiments 3-5 (experiment $3, n=13$ /group; experiment $4, n=7 /$ group; and experiment $5, n=$ 8/group), rats were given access to a single HCD, HFD, or control diet (COND; 25\% protein, $45 \%$ carbohydrate, and 30\% fat; $3.98 \mathrm{Kcal} / \mathrm{gm}$ ). All diets were supplemented with vitamins and minerals as described previously (Shor-Posner et al., 1994).

Test procedures. Food intake and body weight were measured four times per week and once a week, respectively, for the duration of each experiment. For all experiments, rats were killed around dark onset at the end of the 4 week test period, and blood was collected for analysis of corticosterone (CORT), insulin, and glucose. Serum CORT and insulin levels were assayed by RIA similar to the methods of Krey et al. (1975) and of Herbert et al. (1965), respectively. Plasma glucose levels were analyzed with a Beckman Glucose Analyzer No. 2. For experiments 1 and 3, GAL levels were measured by RIA. In experiments 2 and 4, GAL expression and peptide immunoreactivity (ir) were examined using in situ hybridization and immunohistochemistry, and in experiment 5, GAL release from dissected hypothalamic fragments was examined using tissue culture. Unilateral body fat from three regions (inguinal, retroperitoneal, and epididymal) as well as the mesenteric fat pad was collected at the time of death and weighed. Total fat pad weights were recorded.

Radioimmunoassay. Rats were rapidly decapitated; brains were rapidly removed and frozen on dry ice for subsequent analysis. Samples micropunched from nine hypothalamic areas (Jhanwar-Uniyal et al., 1993) were expelled into $2.0 \mathrm{M}$ acetic acid, and GAL-like immunoreactivity was measured as described (Gabriel et al., 1993; Akabayashi et al., 1994c) using polyclonal antisera generated in rabbits to a synthetic rat GAL and rat ${ }^{125}$ I-labeled GAL (Peninsula Laboratories). The samples were reconstituted in assay buffer, and the primary antibody was diluted in buffer containing normal rabbit serum $(1: 75,000$ and $0.5 \%$ final concentration, respectively). Buffer, antibody, samples, or synthetic rat GAL standards were added at the setup and incubated for $72 \mathrm{hr}$ at $4{ }^{\circ} \mathrm{C}$. The radiolabeled GAL was then added, and incubation was continued for $24 \mathrm{hr}$. Phase separation was achieved by the addition of goat anti-rabbit $\gamma$-globulin. The assay has a sensitivity of $4 \mathrm{pg}$, an $\mathrm{ED}_{50}$ of $55 \mathrm{pg}$, and intra- and interassay coefficients of variation of 7 and $18 \%$, respectively.

Immunohistochemistry. For immunohistochemistry, all rats were anesthetized with an overdose of Metofane and were perfused via the ascending aorta with $200 \mathrm{ml}$ of $0.9 \% \mathrm{NaCl}$ followed by $400 \mathrm{ml}$ of $4 \%$ paraformaldehyde in $0.1 \mathrm{~m}$ phosphate buffer, $\mathrm{pH}$ 7.4. Brains were re- moved, post-fixed in the same phosphate-buffered solution overnight at $4^{\circ} \mathrm{C}$, and stored in a $30 \%$ sucrose-phosphate buffer containing $0.01 \%$ sodium azide, $\mathrm{pH} 7.4$, at $4^{\circ} \mathrm{C}$ for $48 \mathrm{hr}$. The brains were then frozen at $-80^{\circ} \mathrm{C}$ until day of use.

Brains were cut into $30-\mu \mathrm{m}$-thick sections with a cryostat. The tissue (Wang and Leibowitz, 1998) was placed in an $80 \%$ methanol PBS solution containing $0.03 \% \mathrm{H}_{2} \mathrm{O}_{2}$ for $30 \mathrm{~min}$. Incubation then occurred with normal goat serum (dilution 1:10 in PBS with $0.5 \%$ Triton X-100) for $30 \mathrm{~min}$. The tissues were then transferred into GAL primary antibody (GAL dilution of 1:20,000; supplied by Dr. Steven Gabriel, Mt. Sinai School of Medicine, New York) at room temperature for 24-48 hr. The tissues were then exposed to secondary antiserum, biotinylated anti-rabbit $\operatorname{IgG}$ (Vectastain Elite Kit; Vector Laboratories, Burlingame, CA), for $1 \mathrm{hr}$. The sections were processed further using standard Vectastain ABC techniques. Staining finally occurred by exposure to $0.05 \mathrm{M}$ Tris- $\mathrm{HCl}$ buffer solution with $0.01 \%$ 3, 3'-diaminobenzidine tetrahydrochloride (Sigma, St. Louis, MO) containing $0.03 \% \mathrm{H}_{2} \mathrm{O}_{2}$. Between each step, the sections were rinsed twice with $0.1 \mathrm{M}$ PBS, pH 7.4. The sections were mounted on slides, dehydrated with graded series of ethanol and xylene, and coverslipped.

In situ hybridization. Rats were killed as described above for immunohistochemistry. Antisense cRNA probes labeled with Digoxigenin were prepared by in vitro transcription. Briefly, a $678 \mathrm{bp}$ HindIII fragment of the rat GAL cDNA (a gift of Dr. Maria E. Vrontakis, University of Manitoba, Winnipeg, Manitoba) was subcloned into a modified plasmid containing a T7 promoter. The GAL plasmid was linearized with HindIII and transcribed in the presence of Digoxigenin-11-UTP (Boehringer Mannheim, Indianapolis, IN), as described previously (Wang and Leibowitz, 1998).

Coronal sections were treated with proteinase $\mathrm{K}(0.001 \%$ proteinase $\mathrm{K}$ in $50 \mathrm{~mm}$ Tris- $\mathrm{HCl}$ and $5 \mathrm{~mm}$ EDTA) for $10 \mathrm{~min}$ and fixed with $4 \%$ paraformaldehyde. After post-fixation, sections were inactivated for endogenous alkaline phosphatase (AP) with $0.2 \mathrm{~N} \mathrm{HCl}$ and acetylated with $0.25 \%$ acetic anhydride (Sigma) for $10 \mathrm{~min}$ each. After dehydration, sections were incubated in hybridization buffer $(50 \%$ formamide, $1 \times$ Denhardt's solution, and $10 \%$ dextran sulfate) and the Digoxigeninlabeled GAL at $55^{\circ} \mathrm{C}$ for $18-24 \mathrm{hr}$. Between each step, sections were rinsed twice in $0.1 \mathrm{M}$ PBS, $\mathrm{pH} 7.2$, for 5 min each.

After hybridization, sections were treated with the following: $5 \times$ SSC wash at $60^{\circ} \mathrm{C}$ for $20 \mathrm{~min}$, a stringent wash in $50 \%$ formamide for $30 \mathrm{~min}$ at $60^{\circ} \mathrm{C}$, and a $30 \mathrm{~min}$ digestion of excess probe with RNase $\mathrm{A}(1 \mu \mathrm{g} / \mathrm{ml})$ at $37^{\circ} \mathrm{C}$. Finally, sections were incubated with sheep anti-Digoxigenin antibody conjugated to AP (anti-dig-AP, Fab fragments; 1:1000; Boehringer Mannheim) for 16-24 hr at room temperature. The developer was freshly prepared by the addition of $50 \mu \mathrm{l}$ of 4-nitroblue tetrazolium chloride solution (NBT; Boehringer Mannheim) and $37.5 \mu \mathrm{l}$ of 5-bromo4-chloro-3-indolyl phosphate solution (BCIP, X-phosphate; Boehringer Mannheim) in $10 \mathrm{ml}$ of Tris buffer (100 mM Tris- $\mathrm{HCl}, 100 \mathrm{~mm} \mathrm{NaCl}$, and $50 \mathrm{~mm} \mathrm{MgCl}_{2}, \mathrm{pH} 9.5$ ) at room temperature in the dark for $4 \mathrm{hr}$ to $1 \mathrm{~d}$. Lastly, the sections were mounted on slides, treated 10 min with $4 \%$ paraformaldehyde, dehydrated using a graded series of ethanol and xylene, and coverslipped.

Quantification of in situ hybridization and immunoreactivity and statistical analysis. A digital imaging system, with the help of a rat brain atlas (Paxinos and Watson, 1986), was used for peptide quantification in brain tissue. Different hypothalamic and extrahypothalamic areas were examined on four anterior-posterior levels: (1) medial preoptic area (MPOA) (bregma, $0.6 \mathrm{~mm}$ ); (2) anterior parvocellular part of the paraventricular nucleus (aPVN), the supraoptic nucleus (SON), and the suprachiasmatic nucleus (SCN) (bregma, $1.4 \mathrm{~mm}$ ); (3) lateral magnocellular part (IPVN) versus medial parvocellular part (mPVN) of a more posterior region of the PVN (bregma, $1.8 \mathrm{~mm}$ ); and (4) arcuate nucleus (ARC), median eminence-external zone (ME), dorsomedial nucleus (DMN), and central nucleus of the amygdala (CNA) (bregma, $2.8 \mathrm{~mm}$ ). The densities of cells or fibers in two to three sections at the same level were measured for each rat. A Leitz microscope was used with an illumination objective of $4 \times$ when focused on the cells and $10 \times$ when focused on the fibers. A video camera connected to an IBM computer with WScan Array Software (Galai Production Ltd.) converted the data to a digital image, each with a gray value ranging from 0 to 255 . To count the number of black pixels, we established a threshold above which pixels were counted. The threshold was the same for all sections counted.

In vitro incubation of hypothalamic tissues. Rats were killed on the day of the experiment by rapid decapitation. The mediobasal portion (MBH) and the mediodorsal portion (MDH) of the hypothalamus were rapidly dissected as described previously (Akabayashi et al., 1994c). Briefly, a 2 $\mathrm{mm}$ coronal section of the brain was made using a brain matrix prechilled 
on wet ice. With the ventral surface of the brain facing up in the matrix, a razor blade was inserted into a slot in the matrix at the caudal optic chiasm, and another razor blade was inserted into a slot $2 \mathrm{~mm}$ caudal to the first blade. The coronal section was removed from the matrix, laid onto a glass plate, and prechilled on wet ice, with the rostral surface of the section facing up. The medial hypothalamus was then dissected freehand, using the top of the third ventricle as the dorsal boundary and the lateral hypothalamic sulci as the lateral boundaries. With the coronal face of the dissection facing up, the block was then dissected in half horizontally to produce the $\mathrm{MBH}$ that includes the $\mathrm{ARC}$ and $\mathrm{ME}$ and the MDH that contains the PVN and DMN.

The single fragment was placed in ice-cold Krebs-Ringer bicarbonate solution (KRB; $118 \mathrm{~mm} \mathrm{NaCl,} 4.6 \mathrm{~mm} \mathrm{KCl,} 1.17 \mathrm{mM} \mathrm{MgSO}_{4}, 1.8 \mathrm{~mm}$ $\mathrm{CaCl}_{2}, 1.17 \mathrm{mM} \mathrm{KH}_{2} \mathrm{PO}_{4}, 25 \mathrm{~mm} \mathrm{NaHCO}_{3}, 180 \mathrm{mg}$ of glucose/100 ml, $10 \mathrm{mg}$ of BSA/100 ml, and $3 \mathrm{mg}$ of bacitracin/100 ml, $\mathrm{pH} \mathrm{7.4);} \mathrm{then} \mathrm{each}$ tissue was transferred into separate wells (24 multiwell plate; Falcone) and incubated at $37^{\circ} \mathrm{C}$ in an atmosphere of $95 \% \mathrm{O}_{2} / 5 \% \mathrm{CO}_{2}$. After $2 \mathrm{hr}$ of preincubation, the medium was aspirated, and the hypothalamic fragment was exposed to KRB for a $30 \mathrm{~min}$ period, followed by exposure to $\mathrm{KCl}$ (36 mM KCl substituted iso-osmotically for the $\mathrm{NaCl}$ ) for $30 \mathrm{~min}$. After collection, the media from each well were immediately acidified with $10 \mu \mathrm{l} 1 \mathrm{~N} \mathrm{HCl}$, lyophilized, and stored at $-80^{\circ} \mathrm{C}$ until GAL RIA was performed. At the end of the incubation, weights of fragments were recorded. Galanin concentration in the in vitro samples was expressed per mg of tissue, as described previously (Kapcala and Weng, 1992).

Data analysis. The Kcal intake of the animals was averaged for a given week, and data are presented as Kcal/24 hr. Body weight, body weight gain, and body fat are calculated for the final week of measurements. With a standard statistical package (SPSS), hypotheses regarding diet groups and brain areas were tested using either a multivariate ANOVA (MANOVA), one-way ANOVA, or two-way ANOVA, followed by a Duncan's new multiple range test for multiple comparisons between groups or an unpaired Student's $t$ test when appropriate. Measures of nutrient intake, body fat, hormones, and hypothalamic GAL were related using a Pearson's product moment correlation. All values are expressed as mean \pm SEM. The criterion for use of the term "significant" in the text is that the probability value $(p)$ for a given test is $<0.05$. Details of the statistical analyses are presented in the legend of each figure.

\section{RESULTS}

\section{GAL in a choice-diet paradigm}

Two experiments were conducted in rats given a choice of the macronutrient diets that allows them to exhibit their natural dietary preferences. In experiment 1 , the subjects were presented two mixed diets (HFD and HCD) from which to choose, whereas in experiment 2, the three pure macronutrient diets were provided. For each experiment, the subjects were divided into two groups based on the amount of fat selected. These two groups, which have at least $25 \%$ protein in their diet, are designated "high-carbohydrate (HC) eaters," with $\sim 45 \%$ carbohydrate and $30 \%$ fat in their diet, and "high-fat (HF) eaters," which select $\sim 50 \%$ fat and $25 \%$ carbohydrate.

\section{Behavioral and hormone measures}

In both the two-diet and three-diet paradigms, the HF eaters after a few weeks on these diets show higher body weight (530$590 \mathrm{gm})$ compared with the HC eaters (440-540 gm; $p<0.01)$. The body fat pad weights of the HF eaters are significantly larger in the two-diet $(+18 \% ; p<0.05)$ as well as in the three-diet $(+27 \% ; p<0.05)$ experiments. The HF and HC eaters also differ in their hormone levels, which were measured in the two-diet experiment (Table 1). Both insulin and CORT levels are significantly $(20-30 \%)$ lower in the HF eaters compared with the HC eaters. This is in contrast to circulating glucose levels, which are $10 \%$ higher $(p<0.05)$ in the HF eaters.

\section{GAL levels in micropunched areas}

In experiment 1 , measurements of GAL via RIA in micropunched samples reveal differences in peptide levels of $\mathrm{HF}(n=8)$ and $\mathrm{HC}$

\section{Table 1. Hormone levels in high-carbohydrate and high-fat eaters}

\begin{tabular}{lcc} 
& $\begin{array}{l}\text { High-carbohydrate eaters } \\
(n=8)\end{array}$ & $\begin{array}{c}\text { High-fat eaters } \\
(n=8)\end{array}$ \\
\hline Insulin $(\mu \mathrm{U} / \mathrm{ml})$ & $90 \pm 5.0$ & $82 \pm 4.0^{*}$ \\
Corticosterone $(\mathrm{ng} / \mathrm{ml})$ & $185 \pm 17$ & $134 \pm 20^{*}$ \\
Glucose $(\mathrm{mg} / \mathrm{dl})$ & $138 \pm 3.0$ & $150 \pm 4.0^{*}$ \\
\hline
\end{tabular}

$\overline{\text { Values are mean } \pm \mathrm{SEM} ;{ }^{*} p<0.05 \text { comparing high-fat to high-carbohydrate eaters. }}$

$(n=8)$ eaters and identify two hypothalamic areas with increased GAL levels in relation to fat ingestion (Fig. 1). One of these areas is the PVN where GAL levels are significantly higher in HF eaters compared with the HC eaters (see Fig. 1 for statistical analyses) and are positively correlated with the amount of fat ingested across all subjects $(r=+0.48 ; p<0.05)$. The other area is the ME where GAL levels are similarly correlated with fat ingestion $(r=+0.65$; $p<0.01)$. The GAL levels in these two hypothalamic sites are positively related to each other $(r=+0.56$; $p<0.05)$ but not to other sites, suggesting their close association. Moreover, although correlated with fat ingestion, they are not related to the consumption of carbohydrate or protein. No group differences and correlations, between GAL and nutrient ingestion, are detected in any of the other hypothalamic sites examined.

\section{GAL $m R N A$ and peptide-ir within hypothalamic nuclei}

In experiment 2, hypothalamic GAL mRNA and peptide-ir, examined using in situ hybridization and immunohistochemistry, are similarly enhanced in the HF eaters $(n=5)$ compared with HC eaters $(n=5)$ (Figs. 2, 3). Via this more precise anatomical analysis, two specific areas are distinguished by their response to dietary fat. One is a specific area of the PVN, the aPVN, which has a dense cluster of GAL-synthesizing neurons, and the other is the $\mathrm{ME}$, in particular, its external zone.

In the HF eaters, the aPVN has a significantly higher expression $(+100 \% ; p<0.05)$ of mRNA in its GAL cell group (Figs. 2, $3 A, B)$, which is positively correlated with the amount of fat ingested in the total group $(r=+0.67 ; p<0.05)$. It also has a $40 \%$ greater density of GAL-containing fibers. The ME shows a similar increase in GAL innervation specifically in its external zone (Figs. 2, 3C,D), the density of which is positively related to GAL mRNA in the aPVN $(r=+0.64 ; p<0.05)$. In contrast to the aPVN, GALexpressing neurons of the lateral PVN (IPVN), which lie immediately caudal to the aPVN, show a small, but statistically insignificant, increase in mRNA level and peptide-ir. The relation between GAL and dietary fat is not evident in other hypothalamic areas or GAL cell groups, including the ARC and MPOA (Fig. 2) in addition to the DMN, SON, and CNA (data not shown).

\section{GAL in a single-diet paradigm}

The results from the choice-diet paradigms, showing a positive relation between GAL in the aPVN-ME areas and the natural preference of the animals for dietary fat, provide the basis for this next series of three experiments in rats given a single diet that offers varying amounts of fat without a choice. In experiment 3 , the rats had one of two diets, either an HCD (65\% carbohydrate) or a HFD ( $60 \%$ fat). In experiments 4 and 5 , they had one of three diets, either the HCD, HFD, or COND with greater balance between fat $(30 \%)$ and carbohydrate $(45 \%)$. Each of these diets contained $25 \%$ protein.

\section{Behavioral and hormone measures}

In each of these experiments, similar behavioral and hormonal patterns were exhibited in relation to the dietary nutrients. These 
Figure 1. Galanin peptide levels (using RIA) in discrete hypothalamic areas of high-carbohydrate $(n=8)$ and high-fat $(n=8)$ eaters in the two diet-choice paradigm (experiment 1). Data are mean \pm SEM. Analysis of the data (via MANOVA) yielded $F_{(9,6)}=22.52, p<$ 0.001 , with direct comparisons (via Duncan's new multiple range test) between the $\mathrm{HC}$ and $\mathrm{HF}$ eaters showing significantly higher GAL levels $(p<0.01)$ in two areas, the PVN and $\mathrm{ME}$, of $\mathrm{HF}$ eaters. $P V N$, Paraventricular nucleus; $A R C$, arcuate nucleus; $M P O A$, medial preoptic area; $S C N$, suprachiasmatic nucleus; $S O N$, supraoptic nucleus; $V M H$, ventromedial nucleus; $D M N$, dorsomedial nucleus; $L H$, lateral hypothalamus; $M E$, median eminence.
High-carbohydrate eaters

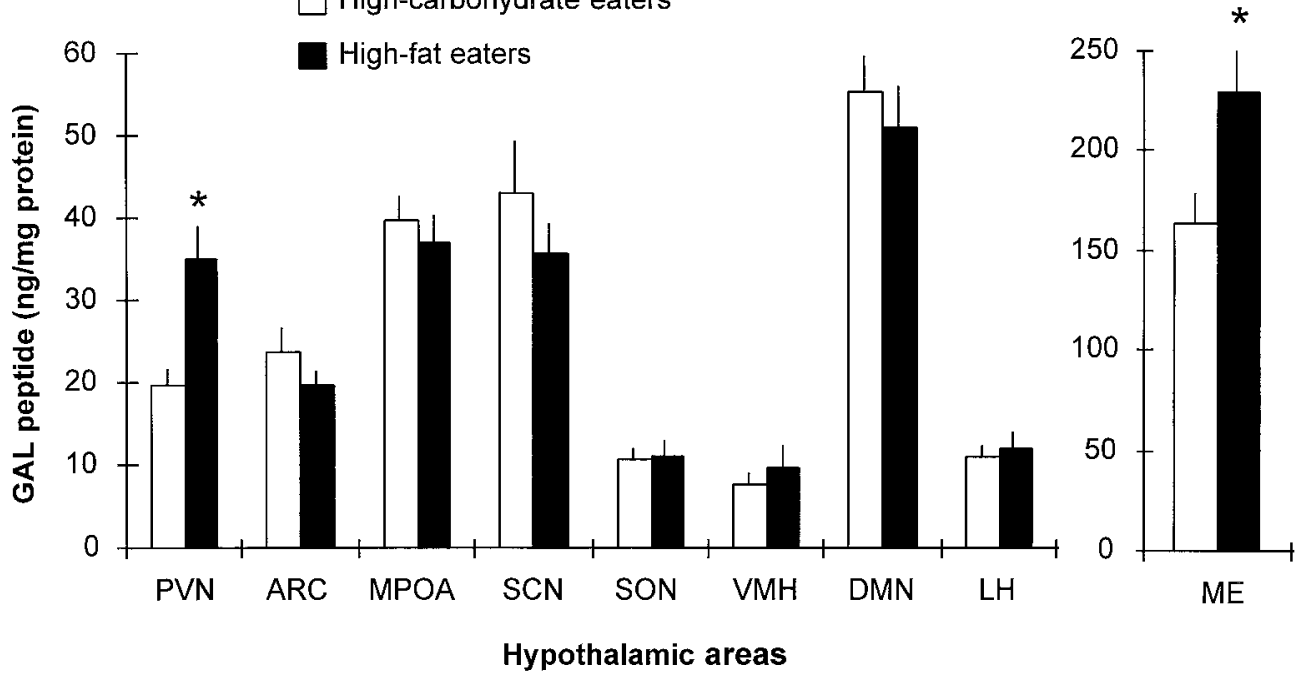

patterns are represented by the results in Figure 4, which illustrate the data obtained with the three diets in experiment 5. When initially placed on the HFD $(n=8)$, compared with the COND $(n=8)$ or HCD $(n=8)$, the rats show significant hyperphagia $(+28 \%$ compared with COND or HCD; $p<0.01)$ during the first 7-10 d. This overeating subsides, and all groups exhibit comparable Kcal intake during subsequent weeks on these diets. As fat intake rises and carbohydrate intake declines, there is an increase in body weight gain $(+73 \% ; p<0.01)$, body weight $(+19 \% ; p<0.01)$, and body fat pad weight $(+100 \% ; p<0.01)$ in the HFD compared with HCD rats.

Endocrine changes are also evident in animals on the different diets (Fig. 4). With the increase in dietary fat from $10 \%$ (HCD) to $30 \%$ (COND), levels of both insulin and CORT decline significantly $(p<0.01)$ by $\sim 15-30 \%$. On the $60 \%$ fat diet (HFD), this endocrine change is sustained but additionally accompanied by a significant rise in blood glucose levels. Glucose levels in rats on the HFD, but not on the HCD or COND, are positively correlated with total Kcal intake and, thus, fat intake on this diet $(r=+0.56 ; p<0.05)$,

\section{GAL levels in micropunched areas}

In this single-diet paradigm, significant changes occur in GAL in association with these diet-induced changes in eating behavior,

\section{Galanin mRNA}

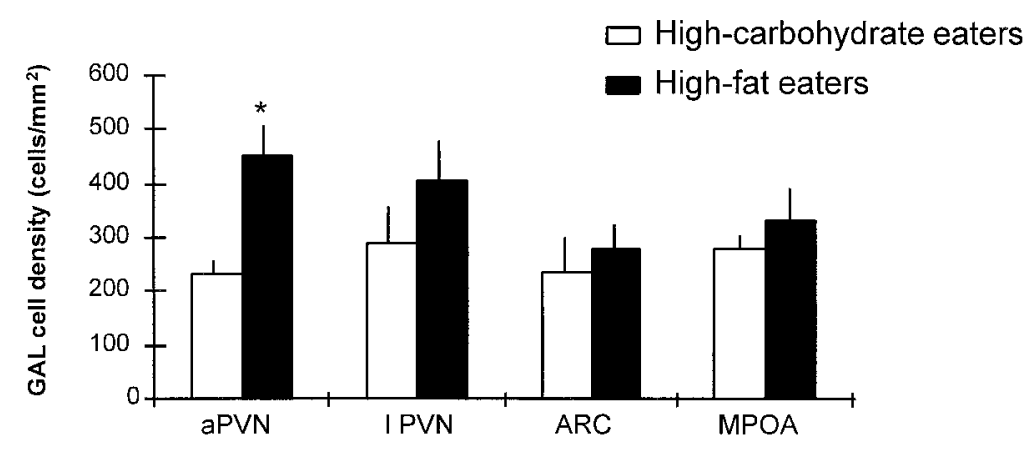

Figure 2. Galanin mRNA and peptide-ir in discrete hypothalamic areas of high-carbohydrate $(n=5)$ and high-fat $(n=5)$ eaters in the three dietchoice paradigm (experiment 2). Data are mean \pm SEM. Analysis of the data (via MANOVA) yielded $F_{(4,5)}=60.47$, $p<0.001$, for GAL mRNA and $F_{(5,4)}=$ $7.31, p<0.04$, for GAL peptide-ir, with direct comparisons (via Duncan's new multiple range test) between $\mathrm{HF}$ and $\mathrm{HC}$ eaters showing significantly higher GAL mRNA levels $(p<0.05)$ in the aPVN only and higher GAL peptide-ir $(p<0.01)$ in the aPVN and ME. $a P V N$, Anterior parvocellular PVN; $l P V N$, lateral PVN. See Figure 1 for additional abbreviations.

\section{Galanin Peptide-ir}
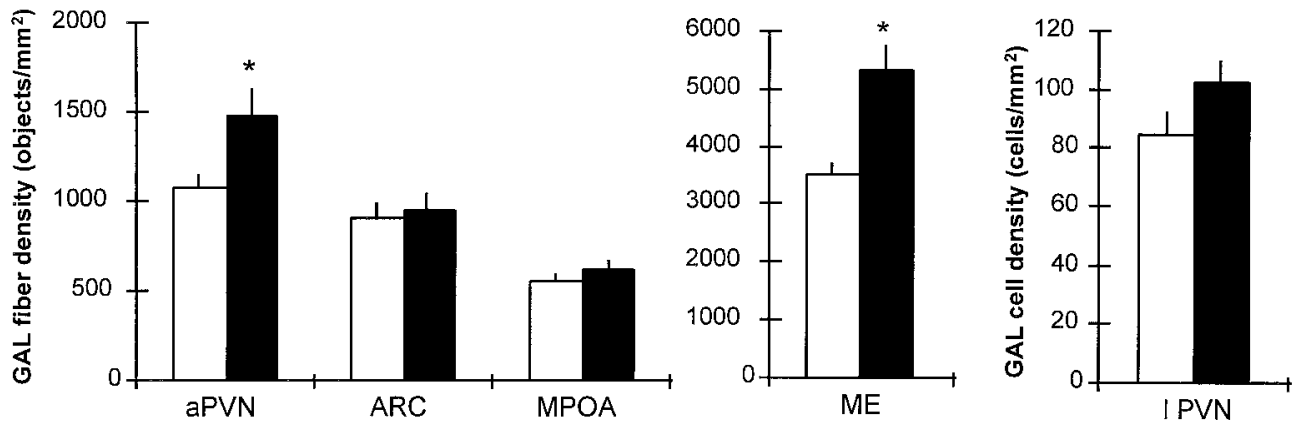

Hypothalamic areas 
HC Eater
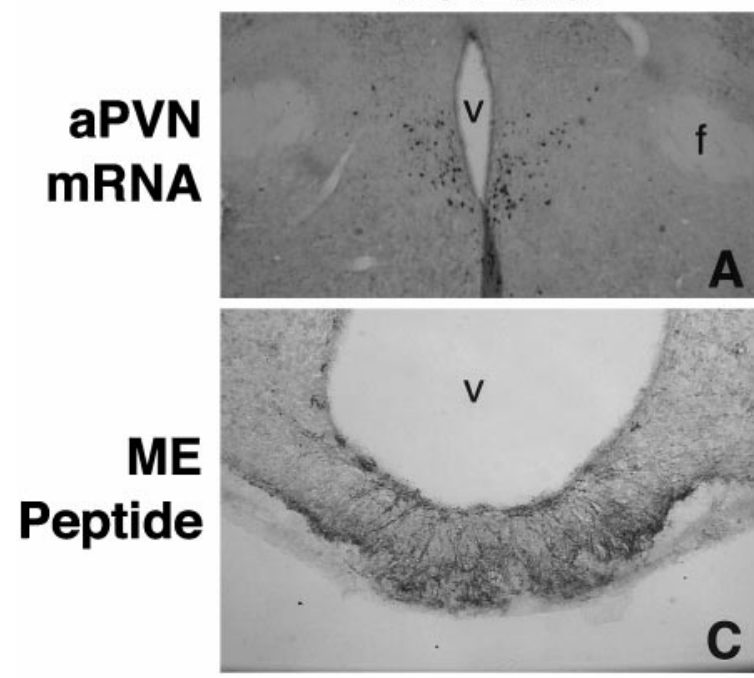

HF Eater
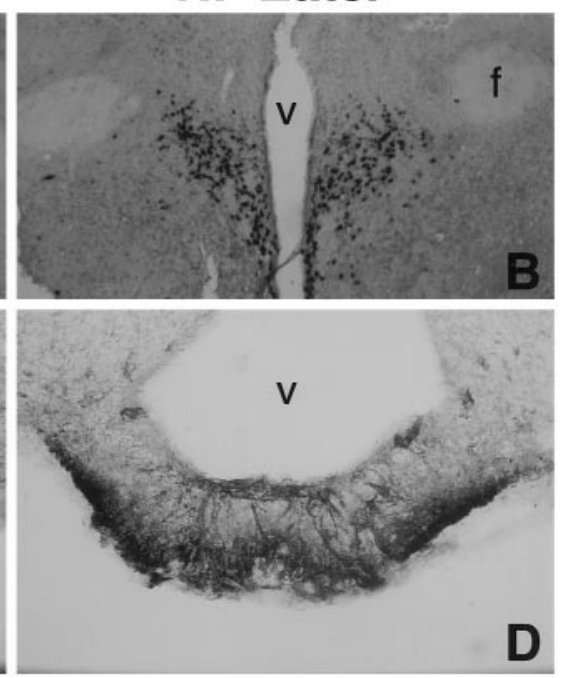

Figure 3. Photomicrographs of GAL mRNA in the aPVN $(A, B$; magnification $40 \times)$ and peptide-ir in the $\operatorname{ME}(C$, $D$; magnification $100 \times)$ of highcarbohydrate (HC) and high-fat (HF) eaters. (See data presented in Fig. 2). V, Third ventricle; $f$, fornix. See Figures 1 and 2 for additional abbreviations. hormones, and body weight. This is seen in experiment 3 , in which the rats were given one of two diets (HCD or HFD), and GAL levels in micropunched hypothalamic nuclei were measured via RIA.

As described for the choice-diet paradigm, two out of the nine brain sites examined are distinguished by their considerably higher levels of GAL peptide in HFD compared with HCD subjects. These areas are the PVN, where GAL is potentiated from $16 \pm 2.3$ to $33 \pm 3.3 \mathrm{ng} / \mathrm{mg}$ of protein $(p<0.01)$, and the $\mathrm{ME}$, where GAL levels of $150 \pm 18 \mathrm{ng} / \mathrm{mg}$ of protein on the HCD rise to $220 \pm 10 \mathrm{ng} / \mathrm{mg}$ of protein on the HFD $(p<0.01)$. All other hypothalamic sites, including the ARC, MPOA, SON, and DMN where dense GAL cell groups exist, show no effect of the diets (data not shown). Furthermore, only in the PVN is the level of GAL positively correlated with total Kcal intake on the HFD $(r=+0.55 ; p<0.05)$.

\section{GAL mRNA and peptide-ir in hypothalamic nuclei}

To provide further information on the nature and anatomical localization of this single diet-induced change, we compared in experiment 4 three groups of rats on a single diet, either HCD $(n=7)$, HFD $(n=7)$, or COND $(n=7)$, using the techniques of in situ hybridization and immunohistochemistry. As illustrated in Figures 5 and 6 (see legends for results of statistical analyses) and Table 2, a rise in dietary fat, from $10 \%$ (HCD) to $30 \%$ (COND), is associated with an increase in GAL gene expression $(+55 \% ; p<0.05)$ in one specific hypothalamic area, the aPVN. This is clearly reflected by the photomicrographs in Figure $6 A-C$. Despite the high abundance of GAL mRNA in other hypothalamic areas, their GAL-synthesizing neurons are unresponsive to diet in these animals (Table 2, Fig. 5). This includes the IPVN, which lies immediately caudal to
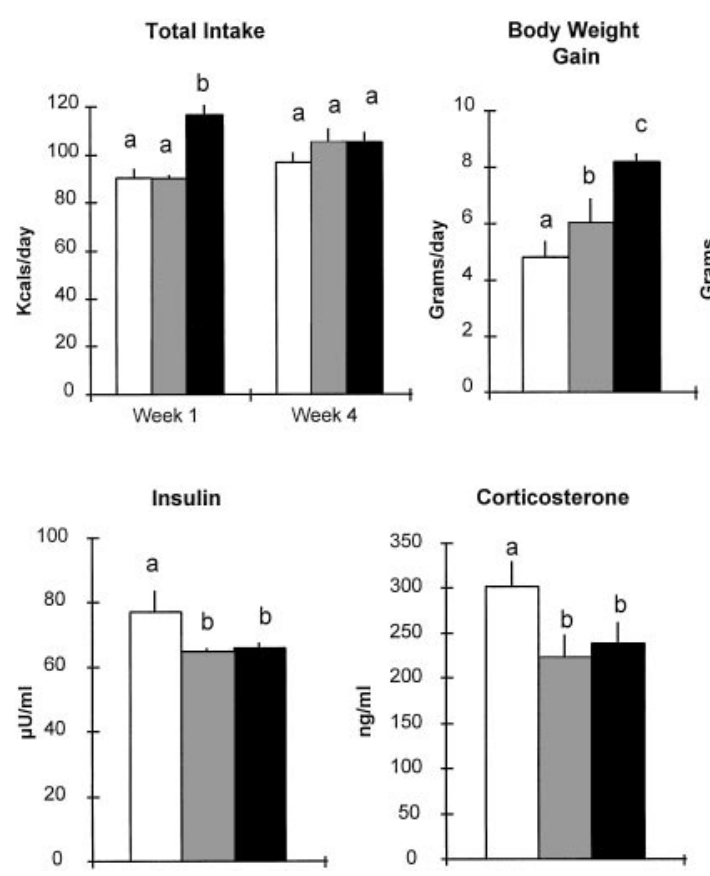

Body Weight
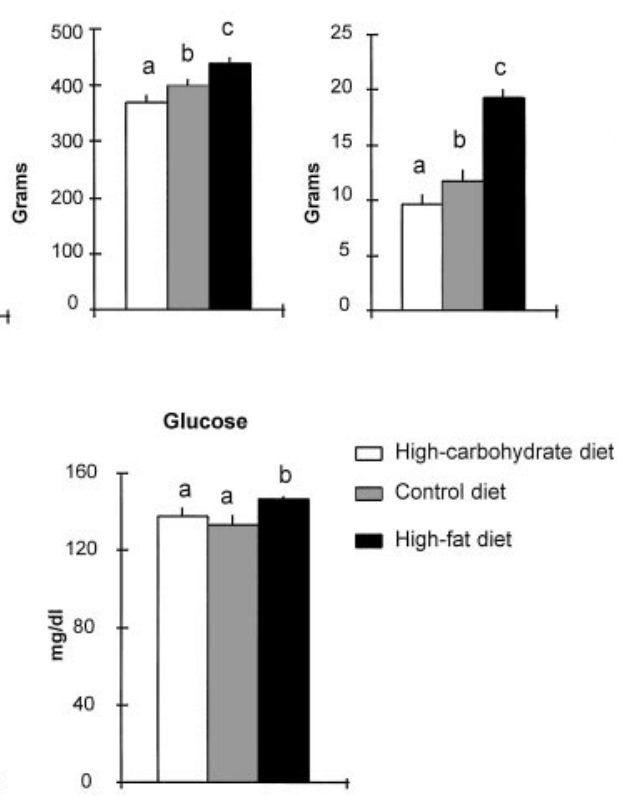

Figure 4. Total Kcal intake, body weight measures, and circulating hormones in rats maintained on a highcarbohydrate diet $(n=8)$, control diet $(n=8)$, or high-fat diet $(n=8)$ (experiment 5). Mean \pm SEM are shown. A one-way ANOVA yielded a significant diet-induced change $(p<0.01)$ for each of these measures, with the exception of total daily intake for week 4 that was similar for the three groups. Shared letters refer to groups that are not significantly different, at $p<0.05$, as determined by the Duncan's new multiple range test. 


\section{Galanin mRNA}

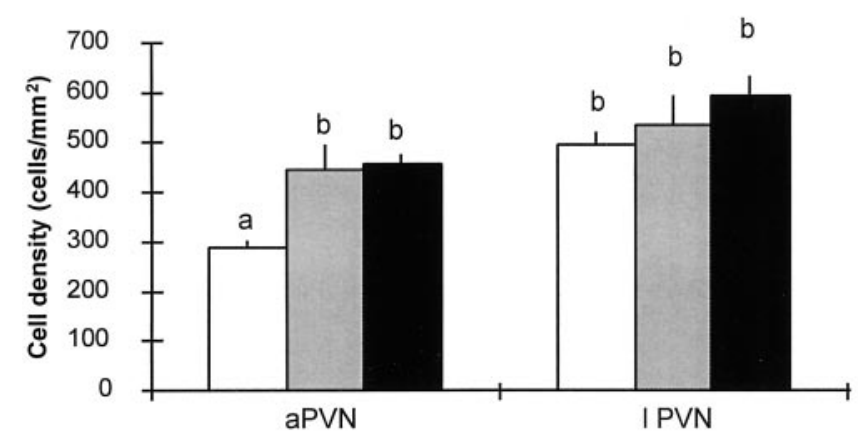

High-carbohydrate diet

Control diet

High-fat diet

Figure 5. Galanin mRNA and peptide-ir in discrete hypothalamic areas of rats on a single HCD $(n=7)$, COND $(n=7)$, or HFD $(n=7)($ experiment 4$)$. Data are mean \pm SEM. Analysis of the data (via MANOVA) yielded $F_{(2,18)}=13.26, p<0.001$, for GAL mRNA and $F_{(3,17)}=32.01, p<$ 0.001, for GAL peptide-ir, with direct comparisons (via Duncan's new multiple range test) between diet groups showing significantly higher GAL mRNA levels $(p<0.05)$ in the aPVN and higher GAL peptide-ir in the aPVN and ME of HFD rats compared with COND and HCD rats. Shared letters refer to groups that are not significantly different, at $p<$ 0.05 , as determined by the Duncan's new multiple range test. See Figures 1 and 2 for abbreviations.

\section{Galanin peptide-ir}

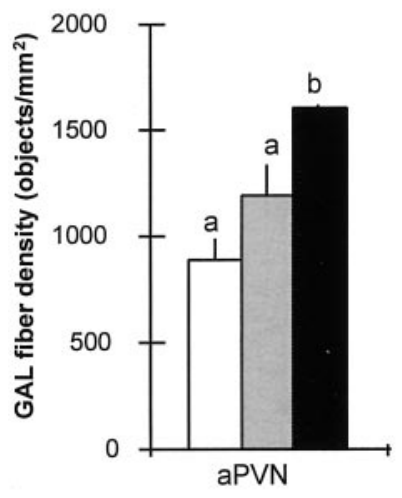

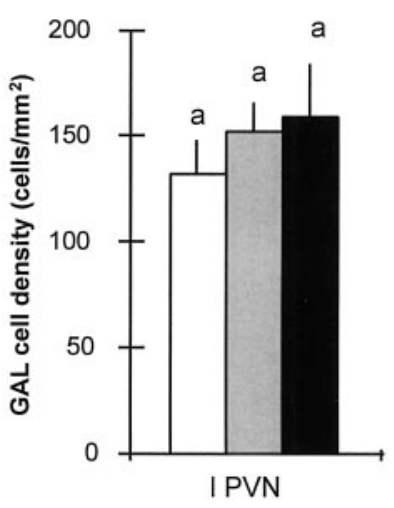

Hypothalamic areas

exhibit a significant rise $(+20 \% ; p<0.05)$ in GAL peptide release after $\mathrm{K}^{+}$stimulation in vitro. No change in basal or $\mathrm{K}^{+}$-stimulated GAL is detected in the $\mathrm{MBH}$ tissue in relation to diet.

\section{GAL in relation to body fat pads}

In the results described above, high dietary fat, whether in one-, two-, or three-diet paradigms, is accompanied by an increase in body weight or body fat that, in turn, is accompanied by higher levels of circulating glucose and increased GAL gene expression or peptide-ir specifically in the aPVN and $\mathrm{ME}$. A relationship between dietary fat and body fat is wellestablished in the literature (Boozer et al., 1995). It is confirmed in the present studies, both the choice-diet paradigm, in which fat intake is positively related to body fat in experiments $1(r=+0.44 ; p<0.05)$ and $2(r=+0.66 ; p<0.05)$, and the single-diet experiments, in which total Kcal intake on a HFD is positively related to body weight or body fat in experiments $3(r=+0.87 ; p<0.01), 4(r=+0.79 ; p<0.05)$, and $5(r=$ $+0.77 ; p<0.05)$. These relationships are absent or considerably weaker in the $\mathrm{HC}$ eaters or HCD group and may actually be inverse when relating carbohydrate intake to body fat (e.g., experiment $2, r=-0.64$ and $p<0.05$ ).

The evidence in experiments 1-5 linking dietary fat to hypothalamic GAL as well as to body fat suggests that GAL, in turn, may itself be related to body fat, possibly functionally linked to circulating hormones or glucose. As indicated above, the most consistent peripheral correlate of body weight or body

Figure 5. Whereas no differences in peptide levels in the media are evident between the COND and HCD rats, the HFD rats
In experiment 5, the release of GAL in vitro, from medial hypothalamic fragments, was examined in tissue taken from HFD $(n=$ $8)$, COND $(n=8)$, or HCD $(n=8)$ rats. The results (Fig. 7$)$, obtained in the MDH fragment wherein the PVN lies, are consistent with those suggested by changes in GAL peptide-ir in 


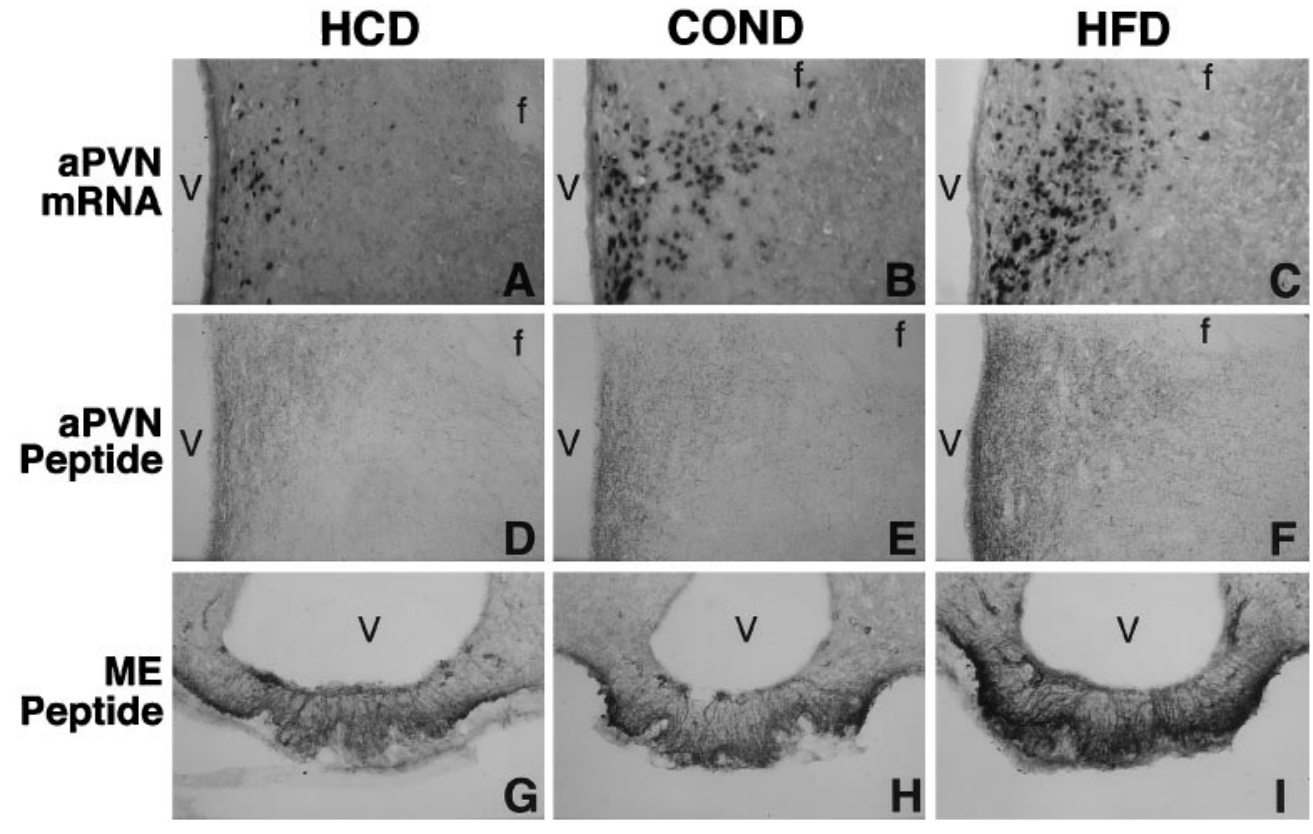

Figure 6. Photomicrographs of GAL mRNA in the aPVN $(A-C)$ and peptide-ir in the aPVN $(D-F)$ and ME $(G-I)$ of rats on a single highcarbohydrate (HCD), control diet (COND), or high-fat diet (HFD). (See data presented in Fig. 5). Magnification, $100 \times$. See Figures 1-3 for additional abbreviations.

\begin{tabular}{|c|c|c|c|c|c|c|}
\hline & $\mathrm{mPVN}$ & MPOA & ARC & DMN & SON & CNA \\
\hline \multicolumn{7}{|c|}{ GAL mRNA (cell density, cells $/ \mathrm{mm}^{2}$ ) } \\
\hline $\mathrm{HCD}$ & $197 \pm 28$ & $298 \pm 28$ & $207 \pm 20$ & $580 \pm 50$ & $489 \pm 33$ & $101 \pm 10$ \\
\hline COND & $125 \pm 6$ & $297 \pm 46$ & $212 \pm 12$ & $570 \pm 45$ & $506 \pm 42$ & $78 \pm 6$ \\
\hline HFD & $159 \pm 10$ & $256 \pm 22$ & $184 \pm 19$ & $590 \pm 50$ & $521 \pm 30$ & $93 \pm 12$ \\
\hline \multicolumn{7}{|c|}{ GAL peptide (fiber density, objects $/ \mathrm{mm}^{2}$ ) } \\
\hline $\mathrm{HCD}$ & $141 \pm 9$ & $635 \pm 64$ & $843 \pm 100$ & $1069 \pm 121$ & $250 \pm 27^{*}$ & \\
\hline COND & $179 \pm 23$ & $565 \pm 42$ & $1006 \pm 148$ & $1042 \pm 94$ & $237 \pm 17^{*}$ & \\
\hline HFD & $186 \pm 22$ & $717 \pm 57$ & $1000 \pm 148$ & $1089 \pm 70$ & $237 \pm 55^{*}$ & \\
\hline
\end{tabular}

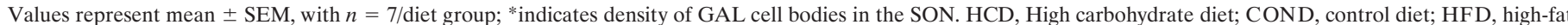
diet; mPVN, medial parvocellular region of PVN; CNA, central nucleus of the amygdala; see legend to Figure 1 for abbreviations of additional brain areas.

fat is blood glucose. This rises significantly in all groups consuming a high-fat diet (Table 1, Fig. 4) and is positively related to body fat in the choice-diet paradigm of experiments $1(r=+0.48 ; p<0.05)$ and $2(r=+0.68 ; p<0.05)$ and also in the single-diet paradigm of experiments $3(r=+0.59$; $p<$ $0.05)$ and $5(r=+0.79 ; p<0.05)$. A direct relationship between hypothalamic GAL and glucose is indicated by a positive correlation between glucose levels and PVN GAL levels $(r=+0.40 ; p<0.05)$ in experiment 1 , ME GAL-ir $(r=$ $+0.56 ; p<0.05)$ in experiment 3 , and $\mathrm{K}^{+}$-evoked GAL release in the $\mathrm{MDH}$ fragment $(r=+0.71 ; p<0.05)$ in experiment 5 .

The possibility that hypothalamic GAL activity may shift in direct relation to body fat is supported by significant positive correlations detected in most experiments. Body fat pad weights are related to GAL levels in the PVN (experiment $1, r=+0.48$ and $p<0.05$; experiment $2, r=+0.63$ and $p<0.05)$, GAL mRNA in the aPVN (experiment $2, r=+0.65$ and $p<0.05$ ), or GAL release in the $\mathrm{MDH}$ of $\mathrm{HFD}$ rats (experiment 5, $r=+0.71$ and $p<0.05)$. It is notable that these relationships in the different experiments, between GAL and circulating glucose or body fat, are consistently apparent in the PVN and ME but not in any other brain area.

To assess the possible relation of GAL to adiposity further, the rats in experiment 1 , which had the largest number of subjects $(n=25)$, were further subgrouped according to their body fat. When consuming a high-fat diet, the subjects exhibit a range of body fat that is sufficiently large to generate an "obesity-prone" group $(n=10)$ with $70 \%$ more body fat $(p<0.01)$ than an "obesity-resistant" group $(n=10)$. A comparison of GAL in these two groups reveals a significant difference in their peptide levels (Fig. 8). The obesity-prone subjects have significantly higher GAL levels in the PVN $(+30 \% ; p<0.05)$ and ME $(+25 \% ; p<0.05)$ but not in any other area (data not shown). Although the subgroups were small ( $n=5$ /group), a similar analysis of the rats in experiment 2, comparing high body fat (40 gm) and low body fat (27 gm) subjects, reveal significantly higher GAL mRNA in the aPVN $(+60 \% ; p<0.01)$ and higher GAL-ir in both the aPVN $(+20 \% ; p<0.05)$ and $\mathrm{ME}(+32 \% ; p<0.05)$. Thus, in groups consuming a high-fat diet, higher levels of GAL are further associated with greater body fat.

\section{DISCUSSION}

This study identifies GAL-expressing neurons and a possible projection site in the hypothalamus that together are linked specifically to dietary fat and, in turn, to increased weight gain and body fat deposition on a high-fat diet. The association with 


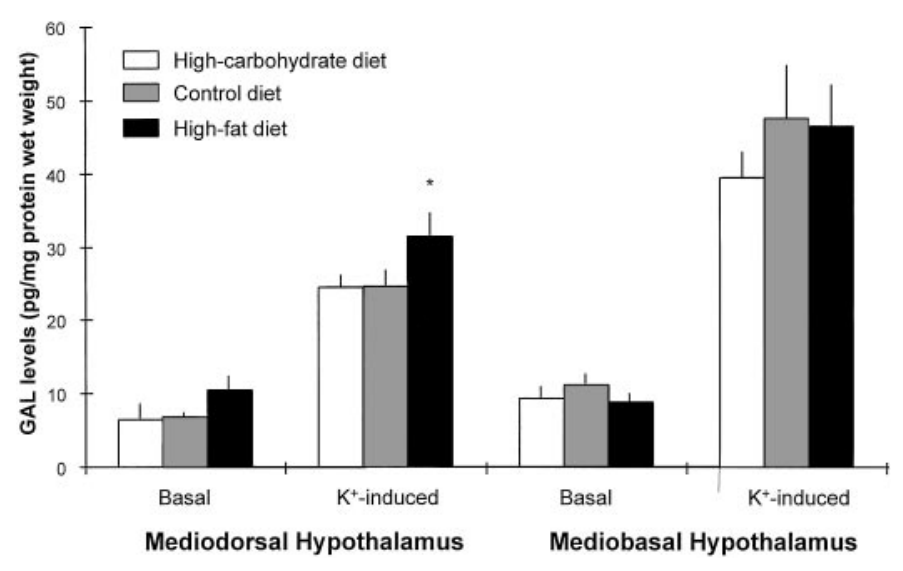

Figure 7. In vitro release of GAL from hypothalamic fragments, mediodorsal and mediobasal, of rats maintained on a single highcarbohydrate diet $(n=8)$, control diet $(n=8)$, or high-fat diet $(n=8)$ (experiment 5). Data are mean \pm SEM. Analyses of the data (via ANOVA) showed a significant increase $(p<0.001)$ in GAL levels after $\mathrm{K}^{+}$stimulation in both areas and in all diet groups. Further analysis of the mediodorsal hypothalamus data yielded $F_{(2,19)}=5.52, p<0.02$, with direct comparisons (via Duncan's new multiple range test) showing significantly greater $\mathrm{K}^{+}$-induced GAL release from the tissue of HFD rats compared with COND or HCD rats $\left({ }^{*} p<0.05\right)$. No significant diet effect was detected in the mediobasal hypothalamus.

dietary fat is demonstrated via analyses of GAL peptide levels in micropunched areas, GAL gene expression and peptide-ir, and GAL release in vitro. It is demonstrated in animals permitted to express their natural preference for the macronutrient diets, as well as in subjects given a single diet varying in fat and carbohydrate content.

\section{Hypothalamic GAL projection and dietary fat}

The first published study relating endogenous GAL activity to fat ingestion measured GAL mRNA using in situ hybridization and GAL peptide levels with RIA (Akabayashi et al., 1994a). Whereas precise anatomical analyses could not be performed using these techniques, the evidence obtained indicated that GAL expression and peptide levels in the area of the PVN are positively related to the natural preference of the animals for fat.

In the present investigation, two specific hypothalamic sites are repeatedly distinguished by a rise in GAL activity in direct relation to the amount of fat consumed by the animals. These are the aPVN, where GAL-synthesizing neurons are dense, and the $\mathrm{ME}$, in particular its external zone, where GAL terminals are concentrated (Fig. 3). The possibility that these two hypothalamic sites are anatomically linked by a projection from the PVN to the ME is supported by histochemical studies (Niimi et al., 1990; Merchenthaler et al., 1993). It is consistent with the present finding that GAL mRNA or peptide levels in the aPVN are positively correlated with GAL-ir in the ME but not in other hypothalamic sites. The type of PVN neurons related to dietary fat seems to be relatively small, compared with the magnocellular neurons that are concentrated in the $1 \mathrm{PVN} \sim 0.3 \mathrm{~mm}$ caudal to the aPVN cell group. In contrast to the GAL fiber of the external zone of the ME, which is a likely projection site for these aPVN neurons (Merchenthaler et al., 1993), the GAL fiber system in the internal zone of the ME, through which IPVN neurons project on their course to the posterior pituitary (Melander et al., 1986), fails to respond to dietary fat.

An additional finding of this report is that this proposed projection, from the aPVN to the ME, is affected similarly by fat consumed spontaneously in a choice paradigm and by fat given in a single-diet paradigm with no choice permitted. Thus, this relationship between GAL and fat reflects, in part, an effect of the diet itself on the activity of this GAL projection. The amount of fat is critical in determining the level of expression and peptide production or release. Whereas GAL expression, but not GAL peptide-ir, is potentiated by an increase in dietary fat from 10 to $30 \%$, an increase in GAL-ir and GAL release occurs predominantly as dietary fat rises above $30 \%$.

\section{Functional significance of the relationship of GAL to dietary fat}

This evidence suggests that GAL in the aPVN-ME projection may have a role in controlling fat ingestion and, ultimately, body fat. Central injection studies provide some support for this relationship. In rats given a choice of diets, GAL stimulates both fat and carbohydrate intake in satiated animals (Tempel et al., 1988; Kyrkouli et al., 1990; Smith et al., 1996), with a stronger effect on preference for fat (Tempel et al., 1988; Chae et al., 1995), and GAL produces a stronger response in animals on a high-fat diet, compared with a high-carbohydrate diet, and in subjects that naturally prefer fat (Barton et al., 1995; Lin et al., 1996). A marked suppression of fat ingestion can be seen with hypothalamic injections of antisense oligonucleotides to GAL mRNA (Akabayashi et al., 1994a), which reduce the consumption of fat over a $24 \mathrm{hr}$ period and cause a significant decrease in GAL production in the PVN. Moreover, a GAL receptor antagonist suppresses the ingestion of fat in a paradigm using macronutrient diets (Leibowitz and Kim, 1992).

This evidence, together with the results of the present investigation, indicates that endogenous GAL, in the aPVN and ME, is part of a positive feedback loop related to dietary fat. That is, this peptide stimulates the ingestion of this nutrient that, in turn, further enhances the activity of this peptide. Although one can only speculate as to the significance of this loop, it is notable that food intake is greatly enhanced by an increase in dietary fat (Ramirez and Friedman, 1990; Tremblay, 1995). This is indicated by the results in Figure 4, showing that rats given a high-fat diet with $60 \%$ fat compared with a control diet of $30 \%$ fat exhibit significant hyperphagia during the first 7-10 d approximately after introduction of the diet. It is further supported by studies showing rising fat content to increase the size of a single meal (Shor-Posner et al., 1994; Warwick, 1996) and palatability of a diet (Rolls and Shide, 1992) and to have reduced satiating capacity relative to the other macronutrients (Shor-Posner et al., 1994; Warwick, 1996). The range of fat that seems to be critical to such hyperphagia is above $30 \%$. This is the same range that is important for the activation of GAL peptide synthesis and release, suggesting that GAL may, in fact, have some role in mediating the hyperphagia associated with fat-rich diets. In this process, GAL may function in close association with the opioid peptides, which have also been linked to the consumption of fat (Tsujii et al., 1987; Barton et al., 1995; Kalra and Kalra, 1996).

\section{Hypothalamic GAL in relation to circulating hormones and glucose}

There is considerable evidence demonstrating the effects of circulating hormones on peptide activity in the brain (Merchenthaler et al., 1993; Dallman et al., 1995; Leibowitz, 1995). The question to be considered here is whether the activity of GAL neurons in the aPVN and ME, when enhanced by a fat-rich diet, is related to the hormone changes produced by this 

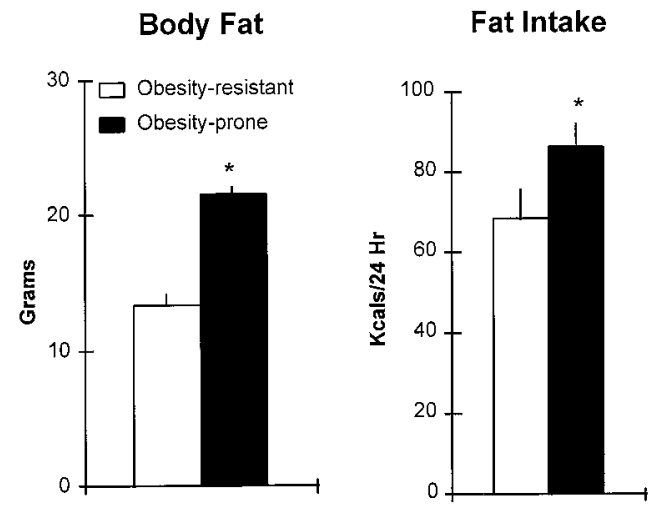

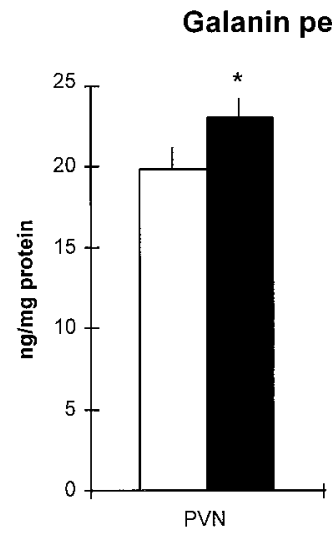

\section{eptide levels}

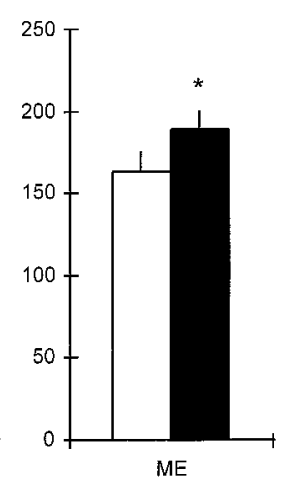

Figure 8. Body fat, fat intake, and GAL peptide levels in the paraventricular nucleus (PVN) and median eminence (ME) of rats (in experiment 1) characterized as obesity-resistant $(n=$ $10)$ or obesity-prone $(n=10)$. See Results for detailed description of the criteria used for subgrouping. Mean \pm SEM are shown; ${ }^{*} p<0.05$ for direct comparisons (via unpaired Student's $t$ test) between obesity-resistant and obesity-prone groups. diet. As shown here, levels of both insulin and CORT are lower on a high-fat diet, both in the choice-diet and single-diet paradigms. This finding, which receives support from published literature (Boivin and Deshaies, 1995; Chicco et al., 1996), suggests that the enhancement of hypothalamic GAL production by dietary fat may be attributed, in part, to this change in hormones. This is possible in light of the evidence suggesting that insulin and CORT may inhibit GAL gene expression in the PVN (Hedlund et al., 1994; Tang et al., 1997; Wang and Leibowitz, 1998). The evidence for insulin is particularly strong, showing an inverse relationship between PVN GAL and circulating hormone levels in diabetic as well as in intact rats (Tempel and Leibowitz, 1990; Akabayashi et al., 1994a,c; Tang et al., 1997). This does not seem to be the only factor, however, because insulin normally inhibits GAL in other hypothalamic cell groups, e.g., in the ARC and DMN (Wang and Leibowitz, 1998), that are not affected by dietary fat.

An additional factor in this relationship may be blood glucose, its uptake and use. Glucose levels on a $60 \%$ rather than a $30 \%$ fat diet rise significantly and are positively correlated with the amount of fat ingested. This change in glucose, observed in other studies (Lawson et al., 1981; Boivin and Deshaies, 1995; Kim et al., 1995), very likely reflects the development of insulin resistance, an inevitable consequence of a high-fat diet (Schrezenmeir, 1996). This suggests that the enhanced GAL production in the aPVN and ME of animals on a high-fat diet may result from a change in glucose uptake, either in peripheral tissues or within the brain itself.

Whereas there is no direct evidence for this possibility, the hypothalamus, including the PVN, is known to have insulin receptors (Unger et al., 1991) and glucose-sensitive areas (Oomura, 1983) and to exhibit changes in peptide production in association with the development of insulin resistance (Leibowitz, 1995; Schwartz and Seeley, 1997). In the pancreas, as in the hypothalamus, GAL has an inhibitory effect on insulin secretion (Tempel and Leibowitz, 1990, 1994; Ahren and Lindskog, 1992). It also stimulates the release of glucagon, consequently raising glucose levels (Lindskog and Ahren, 1989). Thus, a direct relationship between GAL and glucose uptake or use may exist.

\section{Hypothalamic GAL and adiposity}

Whereas it has been known for some years that GAL has a stimulatory effect on eating behavior (Leibowitz, 1995), there is no evidence to date to support a role for this peptide in body weight regulation. One study has demonstrated that repeated injections of GAL antisense oligonucleotides, which suppress
GAL production, can reduce body weight (Akabayashi et al., 1994a). However, tests with repeated injections of GAL into the hypothalamus, although enhancing daily food consumption, have yet to reveal an increase in body weight (Smith et al., 1994).

The results in this report provide the first evidence directly linking GAL to body weight regulation or adiposity. The dual stimulatory effect of a high-fat diet, on body fat and GAL production, supports such a relationship and suggests that it may be expressed specifically under conditions of high dietary fat. In fact, in each of the experiments in which animals are examined in a high-fat condition, a significant positive correlation between GAL and body fat pad weights is evident. Moreover, GAL levels in the PVN are positively related to circulating glucose levels that, in turn, are closely reflective of adiposity as well as of insulin resistance (Golay and Bobbioni, 1997). Furthermore, in obesityprone compared with obesity-resistant rats of the present study, GAL activity is significantly enhanced specifically in neurons of the aPVN and GAL-containing fibers in the external zone of the ME. Consistent with an inhibitory effect of hypothalamic GAL injection on energy expenditure (Menendez et al., 1992) and the increased GAL production in genetically obese rats (Beck et al., 1993; Jhanwar-Uniyal and Chua, 1993; Mercer et al., 1996), the present evidence provides further support for a role of this aPVN-ME projection system in dietary obesity.

\section{REFERENCES}

Ahren B, Lindskog S (1992) Galanin and the regulation of islet hormone secretion. Int J Pancreatol 11:147-160.

Akabayashi A, Koenig JI, Watanabe Y, Alexander JT, Leibowitz SF (1994a) Galanin-containing neurons in the paraventricular nucleus: a neurochemical marker for fat ingestion and body weight gain. Proc Natl Acad Sci USA 91:10375-10379.

Akabayashi A, Watanabe Y, Gabriel SM, Chae HJ, Leibowitz SF (1994b) Hypothalamic galanin-like immunoreactivity and its gene expression in relation to circulating corticosterone. Mol Brain Res 25:305-312.

Akabayashi A, Zaia CT, Koenig JI, Gabriel SM, Silva I, Leibowitz SF (1994c) Diurnal rhythm of galanin-like immunoreactivity in the paraventricular and suprachiasmatic nuclei and other hypothalamic areas. Peptides 15:1437-1444.

Alexander JT, Dourmashkin JT, Manitiu A, Wang J, Leibowitz SF (1996) Hypothalamic galanin and dietary obesity. Soc Neurosci Abstr 22:1409.

Bartfai T, Hokfelt T, Langel U (1993) Galanin-a neuroendocrine peptide. Crit Rev Neurobiol 7:229-274.

Barton C, Lin L, York DA, Bray GA (1995) Differential effects of enterostatin, galanin and opioids on high-fat diet consumption. Brain Res 702:55-60.

Beck B, Burlet A, Nicolas JP, Burlet C (1993) Galanin in the hypothalamus of fed and fasted lean and obese Zucker rats. Brain Res 623:124-130. 
Blundell JE (1987) Nutritional manipulations for altering food intake. Towards a causal model of experimental obesity. Ann NY Acad Sci 499:144-155.

Boivin A, Deshaies Y (1995) Dietary rat models in which the development of hypertriglyceridemia and that of insulin resistance are dissociated. Metabolism 44:1540-1547.

Boozer CN, Schoenbach G, Atkinson RL (1995) Dietary fat and adiposity: a dose-response relationship in adult male rats fed isocalorically. Am J Physiol 268:E546-E550.

Castonguay TW, Hartman WJ, Fitzpatrick EA, Stern JS (1982) Dietary self-selection and the Zucker rat. J Nutr 112:796-800.

Chae HJ, Hoebel BG, Tempel DL, Paredes M, Leibowitz SF (1995) Neuropeptide-Y, galanin and opiate agonists have differential effects on nutrient ingestion. Soc Neurosci Abstr 21:696.

Chicco A, D'Alessandro ME, Karabatas L, Gutman R, Lombardo YB (1996) Effect of moderate levels of dietary fish oil on insulin secretion and sensitivity, and pancreas insulin content in normal rats. Ann Nutr Metab 40:61-70.

Crawley JN, Austin MC, Fiske SM, Martin B, Consolo S, Berthold M, Langel U, Fisone G, Bartfai T (1990) Activity of centrally administered galanin fragments on stimulation of feeding behavior and on galanin receptor binding in the rat hypothalamus. $\mathrm{J}$ Neurosci 10:3695-3700.

Dallman MF, Akana SF, Strack AM, Hanson ES, Sebastian RJ (1995) The neural network that regulates energy balance is responsive to glucocorticoids and insulin and also regulates HPA axis responsivity at a site proximal to CRF neurons. Ann NY Acad Sci 771:730-742.

Gabriel SM, Koenig JI, Washton DL (1993) Estrogen stimulation of galanin gene expression and galanin-like immunoreactivity in the rat and its blockade by the estrogen antagonist keoxifene (LY156758). Regul Pept 45:407-419.

Golay A, Bobbioni E (1997) The role of dietary fat in obesity. Int J Obes 21:S2-S11.

Hedlund PB, Koenig JI, Fuxe K (1994) Adrenalectomy alters discrete galanin mRNA levels in the hypothalamus and mesencephalon of the rat. Neurosci Lett 170:77-82.

Herbert V, Lau KS, Gottlieb CW, Bleicher SJ (1965) Coated charcoal immunoassay of insulin. J Clin Endocrinol Metab 25:1375-1384.

Jhanwar-Uniyal M, Chua Jr SC (1993) Critical effects of aging and nutritional state on hypothalamic neuropeptide $\mathrm{Y}$ and galanin gene expression in lean and genetically obese Zucker rats. Mol Brain Res 19:195-202.

Jhanwar-Uniyal M, Beck B, Jhanwar YS, Burlet C, Leibowitz SF (1993) Neuropeptide Y projection from arcuate nucleus to parvocellular division of paraventricular nucleus: specific relation to the ingestion of carbohydrate. Brain Res 631:97-106.

Kaiyala KJ, Woods SC, Schwartz MW (1995) New model for the regulation of energy balance and adiposity by the central nervous system. Am J Clin Nutr 62:1123S-1134S.

Kalra SP, Kalra PS (1996) Nutritional infertility: the role of the interconnected hypothalamic neuropeptide Y-galanin-opioid network. Front Neuroendocrinol 17:371-401.

Kanarek RB, Orthen-Gambill N (1988) Dietary-induced obesity in experimental animals. In: Use of animal models for research in human nutrition (Beynen AC, West CE, eds), pp 83-110. Basel: Karger.

Kapcala LP, Weng CF (1992) In vitro regulation of immunoreactive $\beta$-endorphin secretion from adult and fetal hypothalamus by sequential stimulation with corticotropin-releasing hormone. Brain Res 588: 13-20.

Kim Y, Iwashita S, Tamura T, Tokuyama K, Suzuki M (1995) Effect of high-fat diet on the gene expression of pancreatic GLUT2 and glucokinase in rats. Biochem Biophys Res Commun 208:1092-1098.

Krey LC, Lu KH, Bulter WR, Hotchkiss J, Piva F, Knobil E (1975) Surgical disconnection of the medial basal hypothalamus and pituitary function in the rhesus monkey. II. GH and cortisol secretion. Endocrinology 96:1088-1093.

Kyrkouli SE, Stanley BG, Leibowitz SF (1986) Galanin: stimulation of feeding induced by medial hypothalamic injection of this novel peptide. Eur J Pharmacol 122:159-160.

Kyrkouli SE, Stanley BG, Seirafi RD, Leibowitz SF (1990) Stimulation of feeding by galanin: anatomical localization and behavioral specificity of this peptide's effects in the brain. Peptides 11:995-1001.

Lawson N, Jennings RJ, Pollard AD, Sturton RG, Ralph SJ, Marsden CA, Fears R, Brindley DN (1981) Effects of chronic modification of dietary fat and carbohydrate in rats. Biochem J 200:265-273.
Leibowitz SF (1995) Brain peptides and obesity: pharmacologic treatment. Obes Res 3:573S-589S.

Leibowitz SF, Hoebel BG (1997) Behavioral neuroscience and obesity. In: The handbook of obesity (Bray G, Bouchard C, James PT, eds). New York: Dekker.

Leibowitz SF, Kim T (1992) Impact of a galanin antagonist on exogenous galanin and natural patterns of fat ingestion. Brain Res 599:148-152.

Lin L, York DA, Bray GA (1996) Comparison of Osborne-Mendel and $\mathrm{S} 5 \mathrm{~B} / \mathrm{PL}$ strains of rat: central effects of galanin, NPY, betacasomorphin and CRH on intake of high-fat and low-fat diets. Obes Res 4:117-124.

Lindskog S, Ahren B (1989) Effects of galanin on insulin and glucagon secretion in the rat. Int $\mathrm{J}$ Pancreatol 4:335-344.

Lissner L, Heitmann BL (1995) Dietary fat and obesity: evidence from epidemiology. Eur J Clin Nutr 49:79-90.

Luiten PG, ter Horst GJ, Steffens AB (1987) The hypothalamus, intrinsic connections and outflow pathways to the endocrine system in relation to the control of feeding and metabolism. Prog Neurobiol 28:1-54.

Melander T, Hokfelt T, Rokaeus A (1986) Distribution of galaninlike immunoreactivity in the rat central nervous system. J Comp Neurol 248:475-517.

Menendez JA, Atrens DM, Leibowitz SF (1992) Metabolic effects of galanin injections into the paraventricular nucleus of the hypothalamus. Peptides 13:323-327.

Mercer JG, Lawrence CB, Atkinson T (1996) Regulation of galanin gene expression in the hypothalamic paraventricular nucleus of the obese Zucker rat by manipulation of dietary macronutrients. Mol Brain Res 43:202-208.

Merchenthaler I, Lopez FJ, Negro-Vilar A (1993) Anatomy and physiology of central galanin-containing pathways. Prog Neurobiol 40:711-769.

Nagase H, Bray GA, York DA (1996) Effect of galanin and enterostatin on sympathetic nerve activity to interscapular brown adipose tissue. Brain Res 709:44-50.

Niimi M, Takahara J, Sato M, Kawanishi K (1990) Immunohistochemical identification of galanin and growth hormone-releasing factorcontaining neurons projecting to the median eminence of the rat. Neuroendocrinology 51:572-575.

Oomura Y (1983) Glucose as a regulator of neuronal activity. Adv Metab Dis 10:31-65.

Paxinos G, Watson C (1986) The rat brain in stereotaxic coordinates, Ed 2. Sydney, Australia: Academic.

Ramirez I, Friedman MI (1990) Dietary hyperphagia in rats: role of fat, carbohydrate, and energy content. Physiol Behav 47:1157-1163.

Ramirez I, Tordoff MG, Friedman MI (1989) Dietary hyperphagia and obesity: what causes them? Physiol Behav 45:163-168.

Rolls BJ, Shide DJ (1992) The influence of dietary fat on food intake and body weight. Nutr Rev [Erratum (1993) 51:31] 50:283-290.

Romsos DR, Ferguson D (1982) Self-selected intake of carbohydrate, fat, and protein by obese (ob/ob) and lean mice. Physiol Behav 28:301-305.

Schrezenmeir J (1996) Hyperinsulinemia, hyperproinsulinemia and insulin resistance in the metabolic syndrome. Experientia 52:426-432.

Schwartz MW, Seeley RJ (1997) The new biology of body weight regulation. J Am Diet Assoc 97:54-58.

Shor-Posner G, Brennan G, Ian C, Jasaitis R, Madhu K, Leibowitz SF (1994) Meal patterns of macronutrient intake in rats with particular dietary preferences. Am J Physiol 266:R1395-R1402.

Smith BK, York DA, Bray GA (1994) Chronic cerebroventricular galanin does not induce sustained hyperphagia or obesity. Peptides 15:1267-1272.

Smith BK, York DA, Bray GA (1996) Effects of dietary preference and galanin administration in the paraventricular or amygdaloid nucleus on diet self-selection. Brain Res Bull 39:149-154.

Swanson LW, Sawchenko PE (1983) Hypothalamic integration: organization of the paraventricular and supraoptic nuclei. Annu Rev Neurosci 6:269-324.

Tang C, Akabayashi A, Manitiu A, Leibowitz SF (1997) Hypothalamic galanin gene expression and peptide level in relation to circulating insulin: possible role in energy balance. Neuroendocrinology 65:265-275.

Tempel DL, Leibowitz SF (1990) Galanin inhibits insulin and corticosterone release after injection into the PVN. Brain Res 536:353-357.

Tempel DL, Leibowitz SF (1994) Adrenal steroid receptors: interactions 
with brain neuropeptide systems in relation to nutrient intake and metabolism. J Neuroendocrinol 6:479-501.

Tempel DL, Leibowitz KJ, Leibowitz SF (1988) Effects of PVN galanin on macronutrient selection. Peptides 9:309-314.

Thomas CD, Peters JC, Reed GW, Abumrad NN, Sun M, Hill JO (1992) Nutrient balance and energy expenditure during ad libitum feeding of high-fat and high-carbohydrate diets in humans. Am J Clin Nutr 55:934-942.

Tremblay A (1995) Nutritional determinants of the insulin resistance syndrome. Int J Obes Relat Metab Disord 19[Suppl 1]:S60-S68.

Tsujii S, Nakai Y, Fukata J, Nakaishi S, Takahashi H, Usui T, Imura H (1987) Effects of food deprivation and high fat diet on immunoreactive beta-endorphin levels in brain regions of Zucker rats. Endocrinol Jpn 34:903-909.
Unger JW, Livingston JN, Moss AM (1991) Insulin receptors in the central nervous system: localization, signalling mechanisms and functional aspects. Prog Neurobiol 36:343-362.

Wade GN, Schneider JE (1992) Metabolic fuels and reproduction in female mammals. Neurosci Biobehav Rev 16:235-272.

Wang J, Leibowitz KL (1998) Central insulin inhibits hypothalamic galanin and neuropeptide $\mathrm{Y}$ gene expression and peptide release in intact rats. Brain Res, in press.

Wang J, Silva I, Harris C, Battacharya M, Leibowitz SF (1996) Hypothalamic galanin gene expression in relation to a high-fat diet in adult male rats. Soc Neurosci Abstr 22:1410.

Warwick ZS (1996) Probing the causes of high-fat diet hyperphagia: a mechanistic and behavioral dissection. Neurosci Biobehav Rev 20: $155-161$. 